Review

\title{
Safety of allogeneic umbilical cord blood infusions for the treatment of neurological conditions: a systematic review of clinical studies
}

\author{
Madison C.B. Paton ${ }^{1, *}$, Donna A. Wall ${ }^{2,3}$, Ngaire Elwood ${ }^{4,5,6}$, Kuang-Yueh Chiang ${ }^{2,3}$, \\ Genevieve Cowie ${ }^{7}$, Iona Novak ${ }^{1}$, Megan Finch-Edmondson ${ }^{1}$ \\ ${ }^{1}$ Cerebral Palsy Alliance Research Institute, Specialty of Child and Adolescent Health, Sydney Medical School, Faculty of Medicine and Health, University of Sydney, \\ Sydney, Australia \\ ${ }^{2}$ Bone Marrow Transplant/Cellular Therapy, Division of Hematology/Oncology, Department of Pediatrics, The Hospital for Sick Children/University of Toronto, \\ Toronto, Canada \\ ${ }^{3}$ Department of Pediatrics, University of Toronto, Toronto, Canada \\ ${ }^{4}$ BMDI Cord Blood Bank, Melbourne, Australia \\ ${ }^{5}$ Murdoch Children's Research Institute, Melbourne, Australia \\ ${ }^{6}$ Department of Pediatrics, University of Melbourne, Melbourne, Australia \\ ${ }^{7}$ Cerebral Palsy Alliance, Sydney, Australia
}

\section{A R T I C L E I N F O}

\section{Article History:}

Received 12 May 2021

Accepted 2 July 2021

\section{Key Words:}

allogeneic

clinical trials

neurological conditions

stem cells

systematic review

umbilical cord blood

\begin{abstract}
A B S T R A C T
Background aims: Umbilical cord blood (UCB) infusion is being investigated as a treatment for a range of neurological conditions, primarily because of its potent immunomodulatory effects mediated via paracrine signaling. Although initial research mainly utilized autologous UCB, allogeneic samples from a sibling or unrelated donor have now become more common. With the use of allogeneic UCB, questions have arisen surrounding the necessity for human leukocyte antigen (HLA) matching, preparative regimens and immunosuppressant drugs. To investigate the safety of allogeneic UCB for the treatment of neurological conditions and the impact of HLA mismatching and immunosuppresion, the authors conducted a systematic review of the safety of allogeneic UCB infusion for neurological conditions.

Methods: A systematic review of published and gray literature was conducted to investigate the safety of allogeneic UCB infusions for neurological conditions.

Results: Authors identified 10 studies using allogeneic UCB to treat autism spectrum disorder, cerebral palsy, stroke, traumatic brain injury and various other conditions. A total of 361 participants (with at least 442 UCB infusions) received a range of HLA-matched/untyped allogeneic units and cell doses, with the majority not administered post-infusion immunosuppression. There were no reported serious adverse events definitely or probably related to the allogeneic UCB infusion, nor later potential complications such as graft-versushost disease or teratoma formation.

Conclusions: Although variability between studies is high, the available data do not identify safety concerns with allogeneic UCB infusion for the treatment of neurological conditions, even with variable HLA matching or no immunosuppression.

(c) 2021 International Society for Cell \& Gene Therapy. Published by Elsevier Inc. This is an open access article under the CC BY license (http://creativecommons.org/licenses/by/4.0/)
\end{abstract}

\section{Introduction}

Umbilical cord blood (UCB) holds potential as a treatment for a range of neurological conditions, including cerebral palsy, autism spectrum disorder and traumatic brain injury [1,2]. UCB contains a mixture of hematopoietic stem and progenitor cells as well as

\footnotetext{
* Correspondence: Madison C.B. Paton, PhD, Cerebral Palsy Alliance Research Institute, Specialty of Child and Adolescent Health, Sydney Medical School, Faculty of Medicine and Health, University of Sydney, 88 Mallett St, Level 4 Building, M02C, Sydney 2050, Australia.

E-mail address: madison.paton@cerebralpalsy.org.au (M.C.B. Paton).
}

regulatory $\mathrm{T}$ and monocyte-derived suppressor cells that could impact the neuroinflammatory environment and make UCB beneficial for treating neurological conditions [3-5]. The goal of UCB infusion for the treatment of neurological conditions is to provide immunomodulation and paracrine signaling to enhance cell survival in damaged tissues, encourage proliferation of progenitor cells and increase angiogenesis [2,6]. UCB has also been shown to protect against neuroinflammation by suppressing microglial activation and T-cell responses [7]. Notably, cells are proposed to be theoretically efficacious even when the recipient is immune-competent and not myeloablated [8]. Engraftment is not the goal, and it is expected that 
the competent immune system of the recipient will not support longterm engraftment [2].

Early clinical trials utilizing UCB as a treatment for neurological conditions used autologous UCB as the infusion product [9]. However, to enhance feasibility, allogeneically sourced UCB has increasingly been studied [10]. Traditionally, allogeneic UCB has been used in the hematopoietic stem cell (HSC) transplant setting for the treatment of hematological malignancies (i.e., blood cancers) and blood disorders [11]. In these situations, the desired outcome is that HSCs in the UCB engraft and reconstitute the recipient's hematopoietic and immune system; hence, the use of immunosuppression regimens and HLA matching between donor and recipient is required. The HLA system is essential in the acceptance and rejection of transplanted tissues [12]. In the allogeneic transplant setting, HLA matching paired with pre-transplant myeloablation reduces the risk of graft rejection, and post-transplant immunosuppression can prevent graft-versus-host disease (GVHD). Notably, UCB for transplantation with the end goal of HSC engraftment is entirely different from UCB infusions [13], particularly for neurological conditions where the goal is immunomodulation.

Despite the clear difference in purpose and function between UCB transplant for replacement of the hematopoietic and immune system and UCB infusion primarily for immunomodulation, there is uncertainty as to whether the immunosuppression and HLA matching that are required in transplantation are needed in the setting of allogeneic UCB infusion for neurological conditions. There has been no consensus across infusion protocols and study designs. The authors therefore aimed to investigate the reported safety of allogeneic UCB in clinical studies of neurological conditions, with a specific focus on degree of HLA mismatching and use of immunosuppression.

\section{Methods}

\section{Criteria for considering studies in this systematic review}

\section{Participants}

The authors included studies that treated human participants with a neurological condition. If studies recruited participants with various conditions that included non-neurological indications, at least $50 \%$ of participants must have been treated for a neurological condition.

\section{Intervention}

The authors included studies that systemically administered (intravenous [IV] or intra-arterial) mononuclear cells (MNCs) (counted as either MNCs or as part of total nucleated cells [TNCs]) obtained from allogeneic UCB. These MNCs must have been considered by the authors to be minimally manipulated (e.g., nonexpanded, non-cultured and non-leukocyte-depleted or irradiated). This did not, however, preclude studies that utilized standard procedures for MNC isolation, such as washing, red blood cell lysis, volume reduction and centrifugation. The authors excluded studies where the intervention was applied in an immune/myeloablated, immunecompromised or immune-suppressed setting (e.g., for malignant conditions) where UCB was intended to reconstitute the hematopoietic system via engraftment. Timing of intervention, number of interventions and dosing restrictions were not applied.

\section{Types of studies}

Any clinical research study, with or without a control group or comparator, was eligible.

\section{Search methods for identification of studies}

The following electronic databases were searched: (i) MEDLINE (from 1946 to January 2021), (ii) Cochrane Central Register of
Controlled Trials in The Cochrane Library (from 2005 to December 2020) and (iii) Embase (from 1947 to January 2021) via Ovid between January 7, 2021, and January 12, 2021. Neurological conditions of interest were defined based on published reviews documenting emerging uses of UCB [14-16] and included Alzheimer's disease, cerebral palsy, stroke, autism spectrum disorder, ataxia, spinal cord injury, amyotrophic lateral sclerosis, encephalopathy and global developmental delay. Searches for neurological conditions were combined with key words designed to limit returns to allogeneic UCB within human/clinical studies. A full description of the search strategy is provided in supplementary File 1.

In addition, the authors electronically and manually searched PubMed, Google Scholar and ClinicalTrials.gov (gray literature) and hand searched the reference lists of included studies to identify any additional relevant studies. All published work from the noted databases or gray literature, including conference abstracts for trials that were also registered at ClinicalTrials.gov, was included.

\section{Data collection and synthesis}

\section{Screening included studies}

MCBP performed all electronic database searches, and two authors independently searched for gray literature (MFE and GC). At title and abstract screening, ineligible studies were excluded. If the title or abstract did not provide sufficient information to determine eligibility, the full text was appraised.

\section{Data extraction}

Two authors (MCBP and GC) extracted the data from included studies. Extracted data included participant information (recruitment age, treatment allocation), methodology (degree of HLA matching, administration details, dosing and use of immunosuppression) and safety outcomes (adverse events [AEs], serious adverse events [SAEs], source of events and other safety parameters). When information was not available, study authors were contacted to obtain data. There was agreement on all extracted data.

\section{Defining toxicities}

For this review, the authors reported all AEs and SAEs as presented by study authors but focused mainly on infusional toxicities and any AE or SAE related to allogeneic UCB. For the purpose of this review, the authors refer to AEs and SAEs and summarize reports as "reported toxicities". AEs and SAEs included serious infusion-related toxicity (e.g., anaphylaxis or desaturation requiring oxygen), teratoma formation (via imaging) and GVHD (based on overall AE/SAE analysis by investigators). Attribution, probability and causality of AEs or SAEs with regard to the allogeneic UCB infusion were also presented as reported by authors. Where detailed, toxicity reporting was captured using common terminology criteria for AEs in standard safety reporting.

\section{Risk of bias and quality assessment}

Two authors (MCBP and IN) independently assessed each included randomized controlled trial for risk of bias using the Cochrane riskof-bias tool 2. For case reports, case series or phase 1 trials with no comparator group, two authors (MCBP and MFE) independently rated the study using a tool for evaluating the methodological quality of case reports and case series [17].

\section{Results}

Electronic database searches returned 87 articles for screening. After screening, five studies met eligibility, and another five eligible articles were identified via manual searching of PubMed, Google Scholar and gray literature (see supplementary File 1) [18-27]. Study characteristics are provided in Table 1. While the authors' article was 
Table 1

Description of included studies.

\begin{tabular}{|c|c|c|c|c|c|c|c|}
\hline $\begin{array}{l}\text { Reference, } \\
\text { ClinicalTrials.gov } \\
\text { registry identifier }\end{array}$ & Study design & Group and participants, n & $\begin{array}{l}\text { Source and intended HLA } \\
\text { matching }\end{array}$ & $\begin{array}{l}\text { Actual HLA matching and } \\
\text { participants, } \mathrm{n}\end{array}$ & $\begin{array}{l}\text { Number of doses, median cells per } \\
\text { dose (range) and route of } \\
\text { administration }\end{array}$ & $\begin{array}{l}\text { Age range } \\
\text { of participants }\end{array}$ & $\begin{array}{l}\text { Details of post-infusion }{ }^{\mathrm{a}} \\
\text { immunosuppression in allo } \\
\text { UCB group }\end{array}$ \\
\hline \multicolumn{8}{|l|}{ Autism } \\
\hline $\begin{array}{l}\text { Dawson et al. [22], } \\
\text { NCT02847182 }\end{array}$ & RCT & $\begin{array}{l}\text { Allo UCB, } 63 \\
\text { Auto UCB, } 56 \\
\text { Placebo, } 61^{\text {b }}\end{array}$ & Unrelated, $\geq 4 / 6 \mathrm{HLA}$ & Not reported & $\begin{array}{l}1 \text { dose, } 3.9(2.1-6.4) \times 10^{7} \mathrm{TNCs} / \mathrm{kg} \text {, } \\
\text { IV }\end{array}$ & $2.3-8.1$ years & No immunosuppression \\
\hline \multicolumn{8}{|l|}{ Cerebral palsy } \\
\hline $\begin{array}{l}\text { Min et al. [18], } \\
\text { NCT01193660 }\end{array}$ & RCT & $\begin{array}{l}\text { Allo UCB + EPO, } 31 \\
\text { EPO, } 33 \\
\text { Placebo, } 32\end{array}$ & Unrelated, $\geq 4 / 6$ HLA & $\begin{array}{l}\text { 5/6 HLA, } 11 \\
4 / 6 \mathrm{HLA}, 20\end{array}$ & $\begin{array}{l}1 \text { dose, } 6.7(4.2-17.2) \times 10^{7} \mathrm{TNCS} / \\
\mathrm{kg} \text {, IV }\end{array}$ & 7 months to 9.8 years & $\begin{array}{l}\text { Cyclosporine (4-week } \\
\text { duration) }\end{array}$ \\
\hline $\begin{array}{l}\text { Kang et al. [26], } \\
\quad \text { NCT01528436 }\end{array}$ & RCT & $\begin{array}{l}\text { Allo UCB, } 17 \\
\text { Placebo, } 17\end{array}$ & Unrelated, $\geq 4 / 6 \mathrm{HLA}$ & $\begin{array}{l}\text { Single units: 5/6 HLA, } 4 \\
\text { 4/6 HLA, } 10 \\
\text { Pooled units: 6/6 + 5/6 HLA, } 1 \\
\text { 5/6 + 4/6 HLA, } 1 \\
\text { 4/6 + 4/6 + 4/6 HLA, } 1\end{array}$ & $\begin{array}{l}1 \text { dose, } 5.5(3.2-7.1) \times 10^{7} \mathrm{TNCs} / \mathrm{kg} \text {, } \\
\operatorname{IV}(\mathrm{n}=15) \text { or IA }(\mathrm{n}=2)\end{array}$ & 6 months to 18 years & $\begin{array}{l}\text { Cyclosporine (13-day dura- } \\
\text { tion) }\end{array}$ \\
\hline $\begin{array}{l}\text { Min et al. [20], } \\
\quad \text { NCT01991145 }\end{array}$ & RCT & $\begin{array}{l}\text { Allo UCB, } 24 \\
\text { Allo UCB + EPO, } 22 \\
\text { EPO, } 20 \\
\text { Placebo, } 22\end{array}$ & $\begin{array}{l}\text { Unrelated, } \\
\geq 4 / 6 \mathrm{HLA}\end{array}$ & $\begin{array}{l}\text { Allo UCB group }{ }^{c} \text { : 6/6 HLA, } 3 \\
5 / 6 \text { HLA, } 10 \\
\text { 4/6 HLA, } 11 \\
\text { Allo UCB + EPO group: } 6 / 6 \text { HLA, } 1 \\
5 / 6 \text { HLA, } 9 \\
4 / 6 \text { HLA, } 12\end{array}$ & $\begin{array}{l}\text { Allo UCB group: } 1 \text { dose, } 5.0 \\
\text { (3.2-9.3) x107 TNCs/kg, IV } \\
\text { Allo UCB + EPO group: } 1 \text { dose, } 4.8 \\
\text { (3.0-7.3) } \times 10^{7} \mathrm{TNCs} / \mathrm{kg}, \text { IV }\end{array}$ & $1-6.3$ years & $\begin{array}{l}\text { Cyclosporine (16-day } \\
\text { duration) }\end{array}$ \\
\hline $\begin{array}{l}\text { Sun et al. [28], } \\
\quad \text { NCT02599207 }\end{array}$ & Single arm & Allo UCB, 15 & $\begin{array}{l}\text { Related, } \\
\geq 4 / 8 \mathrm{HLA}\end{array}$ & $\begin{array}{l}\text { Single units: } 8 / 8 \mathrm{HLA}, 4 \\
\text { 5/8 HLA, } 1 \\
\text { 3/8 HLA, } 10\end{array}$ & $\begin{array}{l}1 \text { dose, } 3.3(1.8-5.2) \times 10^{7} \mathrm{TNCs} / \mathrm{kg} \text {, } \\
\text { IV }\end{array}$ & $1.4-6$ years & No immunosuppression \\
\hline $\begin{array}{l}\text { Romanov et al. [24], } \\
\text { identifier not found }\end{array}$ & Single arm & Allo UCB, 80 & $\begin{array}{l}\text { Unrelated, no HLA match } \\
\text { requirements }\end{array}$ & Not collected/reported & $\begin{array}{l}1 \text { dose }(n=7), 2 \text { doses }(n=18), 3 \\
\text { doses }(n=19), 4 \text { doses }(n=15), 5 \\
\text { doses }(n=14), 6 \text { doses }(n=7) \text {, } \\
31.9^{d}(26.9-39.7) \times 10^{7} \text { TNCs, IV }\end{array}$ & $1-12$ years & No immunosuppression \\
\hline $\begin{array}{l}\text { Feng et al. [25], } \\
\text { identifier not found }\end{array}$ & Single arm & Allo UCB, 47 & $\begin{array}{l}\text { Unrelated, no HLA match } \\
\text { details provided }\end{array}$ & No details provided & $\begin{array}{l}4-8 \text { doses }(\text { mean }=5.4, \text { SD } 1.4), \\
2-3 \times 10^{7} \text { TNCs, first dose IV } \\
\text { then remaining IT }\end{array}$ & $1-29$ years & No immunosuppression \\
\hline \multicolumn{8}{|l|}{ Stroke } \\
\hline $\begin{array}{l}\text { Laskowitz et al. [21 }]^{\mathrm{e}} \text {, } \\
\text { NCT02397018 }\end{array}$ & Single arm & Allo UCB, 10 & $\begin{array}{l}\text { Unrelated, no HLA match } \\
\text { requirements }\end{array}$ & Not collected/reported & $\begin{array}{l}1 \text { dose, } 1.5(0.8-3.3) \times 10^{7} \mathrm{TNCs} / \mathrm{kg} \text {, } \\
\mathrm{IV}\end{array}$ & $45-79$ years & No immunosuppression \\
\hline \multicolumn{8}{|c|}{ Various conditions, including neurological } \\
\hline $\begin{array}{l}\text { Vyas et al. [27], iden- } \\
\text { tifier not found }\end{array}$ & Single arm & $\begin{array}{l}\text { Allo UCB + auto platelet-rich } \\
\text { plasma, } 49^{f}\end{array}$ & $\begin{array}{l}\text { Unrelated, no HLA match } \\
\text { requirements }\end{array}$ & Not collected/reported & $\begin{array}{l}1-3 \text { doses, } 1-2 \times 10^{6} \mathrm{MNCs} / \mathrm{kg} \text {, IV } \\
\text { or IT }\end{array}$ & $3-80$ years & No immunosuppression \\
\hline \multicolumn{8}{|l|}{ Traumatic brain injury } \\
\hline Min et al. [19], N/A & Case report & Allo UCB + EPO, 3 & $\begin{array}{l}\text { Unrelated, } \\
\geq 4 / 6 \mathrm{HLA}\end{array}$ & $\begin{array}{l}\text { Pooled units: } \\
\text { Participant one dose one: } 5 / 6+5 / 6 \\
\text { HLA; dose } 2: 4 / 6+4 / 6 \mathrm{HLA} \\
\text { Participant two dose one: } 4 / 6+4 / \\
\text { 6+ } 4 / 6 \text { HLA; dose two: } 4 / 6+4 / 6 \\
\text { HLA } \\
\text { Participant three dose one: } 4 / 6+4 / \\
\text { 6 HLA; dose two: } 4 / 6+4 / 6 \mathrm{HLA} \\
\end{array}$ & $\begin{array}{l}\text { Participant } 1: 2 \text { doses, } 3.3 \times 10^{7} \\
\text { TNCs } / \mathrm{kg}+3.1 \times 10^{7} \mathrm{TNCs} / \mathrm{kg}, \text { IV } \\
\text { Participant } 2: 2 \text { doses, } 4.6 \times 10^{7} \\
\text { TNCs } / \mathrm{kg}+3.2 \times 10^{7} \mathrm{TNCs} / \mathrm{kg}, \text { IV } \\
\text { Participant } 3: 2 \text { doses, } 2.7 \times 10^{7} \\
\text { TNCs } / \mathrm{kg}+3.8 \times 10^{7} \mathrm{TNCs} / \mathrm{kg} \text {, IA }\end{array}$ & $19-32$ years & $\begin{array}{l}\text { Cyclosporine or tacrolimus (4- } \\
\text { week duration for UCB dose } \\
\text { one, 2-week duration for } \\
\text { UCB dose two) }\end{array}$ \\
\hline
\end{tabular}

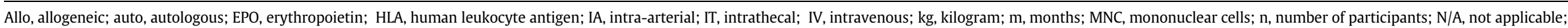
RCT, randomized controlled trial; SD, standard deviation, TNCs, total nucleated cells, UCB; umbilical cord blood, y; years.

a Does not include single corticosteroid administration or any pre-medication for infusion.
b Placebo group received either auto UCB or allo UCB ( $\geq 4 / 6 \mathrm{HLA}$-matched, allogeneic, unrelated UCB donor unit) after primary endpoint (6 months)

c Pooling of two UCB units was allowed to achieve required cell dose; however, no pooling of units specifically noted.

d Included in table as median dose of $31.9 \times 10^{7} \mathrm{TNCs}$ but reported in text as $31.8 \times 10^{7} \mathrm{TNCS}$.

e Incorrect NCT identifier cited in published article.

f $\mathrm{n}=29$ with specified neurological conditions. 
under review, the full trial results from Sun et al. [28] were published. This study was included, and where duplicate publications existed (e. g., conference abstracts plus publication), the findings were reported only once and extracted from the primary source article.

\section{Participants, targeted conditions and types of studies included}

A total of 602 participants across 10 studies were included. Participants were aged 6 months to 90 years. The most common neurological condition studied was cerebral palsy $[18,20,24-26,28]$. The remaining studies targeted autism spectrum disorder [22]; stroke [21]; traumatic brain injury [19]; or a mixture of conditions, including neurological ( $>59 \%$ recruited with a neurological condition [27]. All participant data from Vyas et al. [27] were included in the results, regardless of condition. Of the 10 included studies, four were randomized controlled trials [18,20,22,26], five were single-group allocation studies $[21,24,25,27,28]$ and one was a case report [19].

\section{Details of interventions}

A total of 361 participants received allogeneic UCB as a study intervention with follow-up and safety outcomes collected. One study $(n=15)$ [28] specified that participants received related allogeneic UCB. The other studies either used unrelated UCB or did not specify donor source. Three studies combined allogeneic UCB with erythropoietin [18-20]. One study coupled administration of allogeneic UCB with autologous platelet-rich plasma [27]. Apart from the 361 participants receiving allogeneic UCB, 243 participants received autologous UCB, placebo or standard of care as part of a control or comparator arm/group.

\section{Donor screening and sterility testing of UCB}

Six studies documented methods for stringent maternal infectious disease screening of donor UCB [20,21,23,24,26,27]. Five of these also made note of sterility testing of cryopreserved samples $[20,21,23,24,27]$.

\section{$A B O$ blood group matching}

Three studies specified that allogeneic UCB was ABO blood groupmatched $[20,21,24]$. One study indicated that UCB that was not ABO blood group-matched was used, as units are commonly red blood cell-depleted [27]. The remaining six studies did not specify ABO matching [18,19,22,25,26,28].

\section{Degree of HLA matching}

Allogeneic UCB with a range of HLA matching was used across studies. HLA matching at $>4 / 6$ HLA was required by Dawson et al. [22], but this study did not include details/information about the actual degree of HLA matching between the recipient and allogeneic UCB unit. Five studies (encompassing 112 treated participants) included this HLA matching information [6,18-20,26]. In these studies, 106 participants received a single unit of allogeneic UCB with either a $4 / 6(n=53), 5 / 6(n=34)$ or $6 / 6(n=4)$ HLA match. Furthermore, 10 participants received 4/8 HLA-matched UCB, one received 5/8 HLA and four received 8/8 UCB [28]. Generally, HLA matching was specified as HLA-A, HLA-B and HLA-DRB1. One study that required HLA matching $\geq 4 / 8$ [28] also included HLA-C.

The remaining six participants from two studies $[19,26]$ received pooled units to meet minimum dose requirements. In these instances, multiple allogeneic UCB units of variable HLA match were combined. For example, one participant in a study by Kang et al. [26] received three allogeneic units in one administration that each had a 4/6 HLA match with the recipient but no minimal HLA matching requirements between UCB units. Four studies ( $n=186$ participants) $[21,24,25,27]$ used allogeneic UCB with unspecified HLA matching, with three of these studies using protocols with no HLA matching requirements [21,24,27].

\section{Dosing and delivery schedule}

Most studies administered UCB solely via the IV route $[18,20-22,24,28]$. By contrast, two studies used either IV or intraarterial administration [19,26], one used IV or intrathecal administration [27] and one used both IV and intrathecal administration [25].

Most studies (nine of 10) used cryopreserved UCB, with only the study by Vyas et al. [27] employing infusion of freshly processed UCB. Of the studies using cryopreserved UCB, eight of nine specified that cells were washed to remove the cryoprotectant dimethyl sulfoxide (DMSO) prior to infusion. Feng et al. [25] did not provide cell preparation details.

Across the 10 studies, dosing was either a total dose per patient [24,25] or calculated as TNCs/kg [18-22,26-28] or MNCs/kg [27]. There was a wide range of cells infused. Where specified, cell doses were calculated and reported using post-thaw values for cryopreserved UCB $[21,22,24,28]$. Using TNC count, studies ranged from $0.8 \times 10^{7} \mathrm{TNCs} / \mathrm{kg}$ to $39.7 \times 10^{7} \mathrm{TNCs} / \mathrm{kg}$ per infusion. With regard to studies administering a cell dose irrespective of weight, the median dose was $31.9 \times 10^{7}$ via the IV route for Romanov et al. [24]. In the study by Feng et al. [25], the median dose was $2-3 \times 10^{7}$ cells delivered via IV and intrathecal administration, with a breakdown of dosing for each route not provided.

Of the 361 recipients who received allogeneic UCB, half ( $n=189$, $52.4 \%$ ) received one dose, with 123 participants (34.1\%) receiving two or more (and as high as eight) doses. The remaining 49 participants (13.6\%) reported in the study by Vyas et al. [27] received between one and three doses, but the precise breakdown was not explicitly stated.

\section{Use of immunosuppression}

Four of the 10 studies (all from the same study team and comprising 97 participants) used post-infusion immunosuppression with cyclosporine or tacrolimus for a period of 12 days to 4 weeks [18-20,26]. Across the studies, pre-medication with steroids (methylprednisolone, hydrocortisone), antihistamines and/or acetaminophen to prevent/treat infusional reactions was common and not considered immunosuppression.

\section{Safety of allogeneic UCB and reported toxicities}

\section{AEs and SAEs}

The number of total AEs and SAEs for each study, where available, is reported in Table 2 . In all controlled trials with a comparator group $[18,20,22,26]$, the frequency of both AEs and SAEs was similarly distributed between groups. Moreover, across all studies, no SAEs were deemed to be definitely or probably related to allogeneic UCB. Of the more than 1000 AEs analyzed using these combined data, only one was designated as possibly related to the UCB product (i.e., pruritus of moderate severity, a known risk that resolved on the same day as the infusion) [21]. In addition to standard reporting of AEs/SAEs, the safety of the allogeneic UCB product was frequently discussed further by the researchers (e.g., GVHD, teratoma and HLA antibody formation), and this is also captured in Table 2.

Participants were followed up for safety over a maximum period of 6-36 months post-UCB infusion. Where specified, reporting was conducted at scheduled visits or via e-mail or phone. Reported toxicities and overall safety were captured around the time of infusion and in the following hours to days, with some events being reported longer term (months). Considering all of these reports, the authors interpreted type and presentation and characterized them using the following categories. 
Measures of safety related to allogeneic UCB in included articles.

\begin{tabular}{|c|c|c|c|c|c|c|c|c|c|c|c|}
\hline $\begin{array}{l}\text { Reference, } \\
\text { ClinicalTrials.gov } \\
\text { registry identifier }\end{array}$ & $\begin{array}{l}\text { Duration of } \\
\text { safety follow-up }\end{array}$ & $\begin{array}{l}\text { Total } \\
\text { AEs }\end{array}$ & Participant AE details & $\begin{array}{l}\text { Total } \\
\text { SAEs }\end{array}$ & Details of SAEs & Participant SAE details & $\begin{array}{l}\text { SAES } \\
\text { related } \\
\text { to UCB? }\end{array}$ & Author comments on relevant AEs/SAEs & $\begin{array}{l}\text { Safety comments } \\
\text { related to IS }\end{array}$ & $\begin{array}{l}\text { Incidence of } \\
\text { GVHD }\end{array}$ & $\begin{array}{l}\text { Incidence of } \\
\text { donor-specific HLA } \\
\text { antibody } \\
\text { formation }\end{array}$ \\
\hline $\begin{array}{l}\text { Dawson et al. [22], } \\
\text { NCT02847182 }\end{array}$ & 12 months & 535 & $\begin{array}{l}\text { Percentage of participants } \\
\text { reporting AEs per group } \\
\text { both allo and auto UCB }= \\
81.5 \% \text {, placebo }=83.6 \%\end{array}$ & $6^{\mathrm{b}}$ & $\begin{array}{l}\text { Viral gastroenteritis, dehy- } \\
\text { dration, } \\
\text { Aggression, concussion, } \\
\text { pediatric autoimmune } \\
\text { neuropsychiatric disor- } \\
\text { ders associated with } \\
\text { streptococcal infection }\end{array}$ & $\begin{array}{l}\text { Number of participants } \\
\text { reporting SAEs per group: } \\
\text { allo UCB }=2(3.2 \%) \text {, auto UCB } \\
=1(1.8 \%) \text {, placebo }=3 \\
(4.9 \%)\end{array}$ & No & $\begin{array}{l}\text { - Frequency of AEs similar between } \\
\text { groups. } \\
\text { - Moderate and mild infusion reactions } \\
\text { occurred in all groups, however, all four } \\
\text { severe infusion reactions (characterized } \\
\text { by bronchospasm and/or facial flushing } \\
\text { and swelling) occurred in the allo UCB } \\
\text { group. }\end{array}$ & $\mathrm{N} / \mathrm{A}$ & Not detected & $\begin{array}{l}\mathrm{n}=1 \text { detected at } 6 \\
\text { months }\end{array}$ \\
\hline $\begin{array}{l}\text { Min et al. [18], } \\
\quad \text { NCT01193660 }\end{array}$ & 12 months & 217 & $\begin{array}{l}\text { Number of AEs reported per } \\
\text { group: } \\
\text { allo UCB }+ \text { EPO }=87, \mathrm{EPO}= \\
63 \text {, placebo }=67\end{array}$ & 10 & $\begin{array}{l}\text { Death, pneumonia, influ- } \\
\text { enza, urinary tract infec- } \\
\text { tion, seizure }\end{array}$ & $\begin{array}{l}\text { Number of SAEs reported } \\
\text { per group: } \\
\text { UCB }+E P O=3, E P O=4 \text {, pla- } \\
\text { cebo }=3\end{array}$ & No & $\begin{array}{l}\text { - Frequency of AEs similar between } \\
\text { groups. } \\
\text { - One reported death was not interven- } \\
\text { tion-related. } \\
\text { - Three instances of transient decline in } \\
\text { oxygen saturation (reported as apnea) } \\
\text { in the UCB + EPO group following infu- } \\
\text { sion. Authors noted that this may be } \\
\text { related to first-pass lung sequestration; } \\
\text { howevere, these AEs were also observed } \\
\text { in the EPO and placebo groups. }\end{array}$ & $\begin{array}{l}\text { Higher rates of AEs } \\
\text { in UCB + EPO } \\
\text { group likely due } \\
\text { to IS (not UCB). } \\
\text { Authors com- } \\
\text { mented that use } \\
\text { of IS was not } \\
\text { optimized in } \\
\text { this population. }\end{array}$ & Not detected & Not assessed \\
\hline $\begin{array}{l}\text { Kang et al. [26], } \\
\text { NCT01528436 }\end{array}$ & 6 months & 108 & $\begin{array}{l}\text { Number of AEs reported per } \\
\text { group: } \\
\text { allo UCB }=64 \text {, placebo }=44\end{array}$ & 0 & $\mathrm{~N} / \mathrm{A}$ & $\mathrm{N} / \mathrm{A}$ & No & $\begin{array}{l}\text { - Frequency of AEs similar between } \\
\text { groups. }\end{array}$ & $\begin{array}{l}\text { No safety com- } \\
\text { ment, but } \\
\text { authors noted } \\
\text { that IS may be } \\
\text { neuroprotective. }\end{array}$ & Not detected & Not assessed \\
\hline $\begin{array}{l}\text { Min et al. [20], } \\
\quad \text { NCT01991145 }\end{array}$ & 12 months & 156 & $\begin{array}{l}\text { Number of AEs reported per } \\
\text { group: } \\
\text { allo } U C B=38 \text {, allo UCB }+ \text { EPO } \\
=42, E P O=41 \text {, placebo }= \\
35\end{array}$ & 11 & $\begin{array}{l}\text { Pneumonia, seizure, acute } \\
\text { otitis media, pyrexia, } \\
\text { entropion, viral hepatitis, } \\
\text { nasopharyngitis, labial } \\
\text { frenectomy }\end{array}$ & $\begin{array}{l}\text { Number of SAEs reported } \\
\text { per group: } \\
\text { allo } U C B=1, \mathrm{UCB}+\mathrm{EPO}=3, \\
E P \mathrm{EPO}=3 \text {, placebo }=4\end{array}$ & No & $\begin{array}{l}\text { - Frequency of AEs similar between } \\
\text { groups. }\end{array}$ & $\begin{array}{l}\text { IS for } 16 \text { days did } \\
\text { not increase the } \\
\text { occurrence of } \\
\text { AEs. }\end{array}$ & Not detected & Not assessed \\
\hline $\begin{array}{l}\text { Sun et al. [23,28], } \\
\text { NCT02599207 }\end{array}$ & 2 years & 39 & $\begin{array}{l}\text { Number of participants } \\
\text { reporting AEs: } \\
\mathrm{n}=14 / 15(93.3 \%)\end{array}$ & 10 & $\begin{array}{l}\text { Prolongued or increased } \\
\text { febrile seizures, dehydra- } \\
\text { tion, constipation, } \\
\text { cellulitus }\end{array}$ & $\begin{array}{l}\text { Number of participants } \\
\text { reporting SAEs: } \\
\mathrm{n}=9 / 15(60 \%)\end{array}$ & No & $\begin{array}{l}\text { - UCB administration was well tolerated, } \\
\text { with no acute infusion reactions and no } \\
\text { unexpected imaging findings. } \\
\text { - No platelet antibodies, red blood cell } \\
\text { antibodies or donor cells were detected } \\
\text { in peripheral blood } 6 \text { months after infu- } \\
\text { sion. }\end{array}$ & $\mathrm{N} / \mathrm{A}$ & Not detected $^{c}$ & $\begin{array}{l}\text { None detected at } 6 \\
\text { months }\end{array}$ \\
\hline $\begin{array}{l}\text { Romanovet al. } \\
\text { [24], identifier } \\
\text { not found }\end{array}$ & $\begin{array}{l}3 \text { months } \\
\text { to } 3 \text { years }\end{array}$ & 0 & $\mathrm{~N} / \mathrm{A}$ & 0 & $\mathrm{~N} / \mathrm{A}$ & $\mathrm{N} / \mathrm{A}$ & No & $\begin{array}{l}\text { - Authors reported that UCB administra- } \\
\text { tion was well tolerated, with no acute } \\
\text { or delayed AEs. }\end{array}$ & $\mathrm{N} / \mathrm{A}$ & Not detected & Not assessed \\
\hline $\begin{array}{l}\text { Feng et al. [25], } \\
\text { identifier not } \\
\text { found }\end{array}$ & 6 months & 42 & $\begin{array}{l}\text { Number of participants } \\
\text { reporting AEs: } \\
\mathrm{n}=26 / 47 \text { (55.3\%) }\end{array}$ & 0 & $\mathrm{~N} / \mathrm{A}$ & $\mathrm{N} / \mathrm{A}$ & No & $\begin{array}{l}\text { - No AEs related to IV infusions of UCB. } \\
\text { - All AEs related to IT administration of } \\
\text { UCB or participant age ( } \leq 10 \text { years). }\end{array}$ & $\mathrm{N} / \mathrm{A}$ & Not detected & Not assessed \\
\hline $\begin{array}{l}\text { Laskowitz et al. } \\
\quad[21], \\
\quad \text { NCT02397018 }\end{array}$ & 12 months & 113 & $\begin{array}{l}\text { Number of participants } \\
\text { reporting AEs: } \\
\mathrm{n}=10 / 10(100 \%)\end{array}$ & 8 & $\begin{array}{l}\text { Sepsis secondary to urinary } \\
\text { tract infection, chronic } \\
\text { paralytic ileus }\end{array}$ & $\begin{array}{l}\text { Number of participants } \\
\text { reporting AEs: } \\
\mathrm{n}=2 / 10(20 \%)\end{array}$ & No & $\begin{array}{l}\text { - One AE (pruritus of moderate severity) } \\
\text { was deemed possibly related to UCB. } \\
\text { - No AEs were deemed definitely or prob- } \\
\text { ably related. }\end{array}$ & $\mathrm{N} / \mathrm{A}$ & Not detected & $\begin{array}{l}\text { Assessed but not } \\
\text { reported }\end{array}$ \\
\hline $\begin{array}{l}\text { Vyas et al. [27], } \\
\text { identifier not } \\
\text { found }\end{array}$ & $\mathrm{N} / \mathrm{S}$ & $\begin{array}{l}\text { Not } \\
\text { reported }\end{array}$ & $\begin{array}{l}\text { Number of participants } \\
\text { reporting AEs: between } n \\
=4 / 49 \text { and } n=11 / 49^{d}\end{array}$ & 0 & $\mathrm{~N} / \mathrm{A}$ & $\mathrm{N} / \mathrm{A}$ & No & $\begin{array}{l}\text { - No evidence of sensitization. } \\
\text { - Safety data were suggestive of no } \\
\text { immune response. }\end{array}$ & $\mathrm{N} / \mathrm{A}$ & Not detected & Not assessed \\
\hline Min et al. [19], N/A & $\begin{array}{l}18 \text { months } \\
\text { to } 2 \text { years }\end{array}$ & 10 & $\begin{array}{l}\text { Number of participants } \\
\text { reporting AEs: } \\
\mathrm{n}=3 / 3(100 \%)\end{array}$ & 0 & $\mathrm{~N} / \mathrm{A}$ & $\mathrm{N} / \mathrm{A}$ & No & $\begin{array}{l}\text { - Some minor AEs possibly related to IV } \\
\text { infusion of UCB (cell entrapment) or } \\
\text { immunosuppression. } \\
\text { - No immunoreactivity or tumor forma- } \\
\text { tion noted. }\end{array}$ & $\begin{array}{l}\text { Transient AEs } \\
\text { related to IS } \\
\text { were noted (no } \\
\text { SAEs). }\end{array}$ & Not detected & Not assessed \\
\hline
\end{tabular}

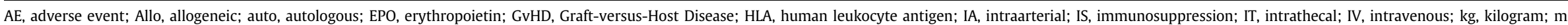

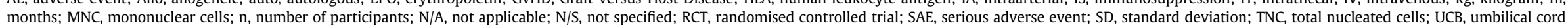
blood; $y$, years.
a

b Includes SAEs from participants in crossover placebo group treated with UCB.

b Includes SAEs from participants in crossover placebo group treated with UCB.
c Two participants developed HLA antibodies, but these were not donor-specific.

d AEs reported as number of participants experiencing each AE, with possibility that each participant could experience multiple AEs. 
Infusional toxicities. Dawson et al. [22] noted four severe infusion reactions (bronchospasm and/or facial flushing and swelling) in those receiving allogeneic $U C B$, with only mild reactions seen in placebo and autologous UCB groups. In addition, Min et al. [18] observed three instances of transient decline in oxygen saturation, likely due to trapping of cells in the lungs. Otherwise, no infusion reactions were reported.

It was noted in two studies $[19,25]$ that route of administration (particularly intrathecal) as well as possible cell entrapment in the infusion line may have contributed to higher AEs or infusional toxicities. In the study by Feng et al. [25], it was also noted that younger children ( $\leq 10$ years) given allogeneic UCB intrathecally were at higher risk of an $\mathrm{AE}$, likely due to a number of reasons, including high cell dose and general immune immaturity.

Immune responses. In the one study that assessed immune response and persistence, no platelet antibodies, red blood cell antibodies or donor cells were detected in peripheral blood 6 months after infusion [28]. Infusion of UCB was noted in multiple studies as being generally well tolerated, with no immunoreactivity $[19,24,27,28]$. There were no reports of GVHD in any study, noting that GVHD is typically diagnosed from clinical analysis of AEs and SAEs gathered over the reporting period.

Three studies analyzed the formation of donor-specific HLA antibodies following allogeneic UCB administration [21,22,28], the rationale being that allogeneic cells may elicit anti-HLA antibody production (as with any leukocyte-replete blood product). Across the 88 participants assessed, there was only one report of donor-specific
anti-HLA antibody formation and two reports of non-donor-specific HLA antibody formation from a single study [28].

Teratomas and malignancy formation. There were no reports of tumor formation or other malignancies.

Immunosuppression. Across all four studies that used immunosuppression, no SAEs were attributed to its use [18-20,26]. Two studies $[18,19]$ found that some AEs were attributable to the use of immunosuppression. By contrast, Min et al. [20] found no increase in the overall incidence of AEs due to immunosuppression.

\section{Risk of bias and quality assessment of included studies}

Quality assessments of case reports and single-arm studies are presented in Table 3 . No study scored more than $6 / 8$ overall, with a total score ranging from 1 to 6 . Randomized controlled trials assessed using the Cochrane risk-of-bias tool 2 were scored and are presented in Table 4. Overall bias was found to be "low" in all studies assessed.

\section{Discussion}

Allogeneic UCB infusion for the treatment of neurological conditions is an emerging strategy. This is the first systematic review of the safety of this approach. The authors' review of 10 clinical studies did not identify any unexpected safety concerns related to allogeneic UCB across 361 patients and more than 442 infusions for a range of

Table 3

Quality assessment for non-randomized studies.

\begin{tabular}{|c|c|c|c|c|c|c|c|}
\hline \multirow[b]{2}{*}{ Domain } & \multirow[b]{2}{*}{ Leading explanatory question } & \multicolumn{6}{|c|}{ Study } \\
\hline & & Min et al. [19] & Sun et al. [28] & Romanov et al. [24] & Feng et al. [25] & Laskowitz et al. [21] & Vyas et al. [27] \\
\hline Selection & $\begin{array}{l}\text { 1. Do patients represent the whole } \\
\text { investigator (center) experience? }\end{array}$ & No & Yes & Yes & Yes & Yes & No \\
\hline \multirow[t]{2}{*}{ Ascertainment } & $\begin{array}{l}\text { 2. Was the exposure adequately } \\
\text { ascertained? }\end{array}$ & Yes & Yes & Yes & Yes & Yes & Yes \\
\hline & $\begin{array}{l}\text { 3. Was the outcome adequately } \\
\text { ascertained? }\end{array}$ & Yes & Yes & No & Yes & Yes & No \\
\hline \multirow[t]{4}{*}{ Causality } & $\begin{array}{l}\text { 4. Were alternative causes explain- } \\
\text { ing the observation ruled out? }\end{array}$ & Yes & Yes & No & No & Yes & No \\
\hline & $\begin{array}{l}\text { 5. Was there a challenge/rechallenge } \\
\text { phenomenon? }^{\mathrm{a}}\end{array}$ & $\mathrm{N} / \mathrm{A}$ & $\mathrm{N} / \mathrm{A}$ & $\mathrm{N} / \mathrm{A}$ & $\mathrm{N} / \mathrm{A}$ & $\mathrm{N} / \mathrm{A}$ & $\mathrm{N} / \mathrm{A}$ \\
\hline & $\begin{array}{l}\text { 6. Was there a dose-response } \\
\text { effect? }^{\text {a }}\end{array}$ & No & No & No & Yes & No & No \\
\hline & $\begin{array}{l}\text { 7. Was follow-up long enough for } \\
\text { outcomes to occur? }\end{array}$ & Yes & Yes & Yes & Yes & Yes & No \\
\hline Reporting & $\begin{array}{l}\text { 8. Was there sufficient detail to repli- } \\
\text { cate the research? }\end{array}$ & Yes & Yes & Yes & Yes & Yes & No \\
\hline Overall score & & $5 / 8$ & $6 / 8$ & $4 / 8$ & $6 / 8$ & $6 / 8$ & $1 / 8$ \\
\hline
\end{tabular}

Quality assessment tool from Murad et al., 2011 [17]. "Yes" scores 1 and "No" scores 0.

N/A, not applicable.

${ }^{a}$ Mostly relevant to cases of adverse drug events.

Table 4

Quality assessment of randomized controlled trials using Cochrane risk-of-bias tool 2.

\begin{tabular}{lllll}
\hline Domain and signaling questions & \multicolumn{3}{c}{ Study } \\
\cline { 2 - 5 } & Dawson et al. [22] & Min et al. [20] & Min et al. [18] & Kang et al. [26] \\
\hline 1 Risk of bias arising from the randomization process & Low & Low & Low & Low \\
2 Risk of bias due to deviations from intended interventions & Low & Low & Low & Low \\
3 Risk of bias due to missing outcome data & Low & Low & Low & Low \\
4 Risk of bias in measurement of the outcome & Low & Low & Low & Low \\
5 Risk of bias in selection of the reported result & Low & Low & Low & Low \\
Overall risk of bias & Low & & & Low \\
\hline
\end{tabular}


neurological conditions (i.e., autism spectrum disorder, cerebral palsy, stroke, traumatic brain injury and various other indications). When delivered as a simple systemic infusion without immunosuppression, there were no safety issues identified outside of the expected infusion reactions routinely seen with blood products or DMSO. This included recipients of multiple doses (up to eight) or pooled UCB units. There were no reports of GVHD or teratoma formation, which is consistent with aggregate data of similar cell therapies [29].

Expected toxicities were related to the nature of preparing, storing and administering the cell product and not the allogeneic UCB itself. For example, some infusion reactions were likely associated with trace cryoprotectant (DMSO) remaining after cell washing. There were also expected transient effects attributable to cell entrapment during infusions or first-pass lung sequestration.

Safety data presented in this review are consistent with other mild, treatable and expected events included in reports regarding systematically administered cells across other conditions [29-32]. Of relevance, UCB infusion can be likened to whole blood transfusions without the use of leukodepletion protocols, which are still safely used today [33-35]. Importantly, UCB has a lower risk profile compared with adult blood infusions [8,12]. This is due, among other reasons, to UCB having lower hemagglutinin titers. The majority of studies also did not specify or require $\mathrm{ABO}$ matching since banked cord blood is routinely red blood cell-depleted, making $A B O$ and rhesus matching less of a consideration [27,36].

\section{Considering the need for immunosuppression in allogeneic UCB infusion} protocols

Where mentioned by authors, the inclusion of systemic immunosuppression as part of the treatment strategy following infusion in some of the studies was intended to lower the theoretical risk of GVHD and/or increase efficacy by prolonging cell persistence. The need for immunosuppression in the setting of UCB infusion has been questioned in the literature previously [37]. It is beyond the ability of this review to comment on whether immunosuppression is needed/ beneficial since only four studies applied immunosuppression postinfusion and only for a relatively short time period ( $<2$ weeks in one instance [26]). Irrespective of the use of immunosuppression, there were no reports of GVHD. Therefore, immunosuppression is not required for safety, but the authors cannot discount the potential immunosuppression may have in promoting treatment efficacy of UCB.

\section{HLA requirements in allogeneic UCB infusion protocols}

Lesser or greater HLA mismatching did not appear to impact the toxicity of allogeneic UCB infusions or later potential complications. As with the role of immunosuppression, the need for HLA matching to any degree when treating neurological conditions is unclear. The authors encourage further research that captures longer-term outcomes that may be relevant to HLA matching, including cell persistence and anti-HLA or anti-platelet/red cell antibody formation. The impact of donor HLA antibody formation-and whether it is, in fact, a risk for people in a non-myeloablated setting-requires investigation [38]. However, again, the risk is similar to that of commonly used non-leukofiltered blood transfusions [33-35]. Safety risk may be more relevant if repeat dosing of allogeneic UCB becomes a therapeutic norm. Theoretically, there may be increased risk of toxicity if higher cell doses or multiple transfusion exposures result in recipient sensitization to donor alloantigens [12].

Theoretically, a greater HLA-matched allogeneic UCB infusion may promote efficacy because of increased cell persistence, yet there is currently no clinical data regarding early (i.e., days or weeks postinfusion) cell persistence following allogeneic UCB infusion. The only published data are from one report confirming that cells are no longer circulating in peripheral blood after 6 months [28]. However, ultimately, the authors know from published pre-clinical evidence that UCB cells do not need to persist, as sustained functional recovery is observed even months after cells stop being detected $[39,40]$. The field would benefit from confirming this in clinical trials. There is one clinical trial that has collected earlier cell persistence data [41]; however, these have not yet been published.

\section{Limitations}

The authors acknowledge that there are limitations of this review. By including studies that did not report safety as a primary outcome, it is possible that toxicity reporting is underrepresented. Along with incomplete toxicity reporting, the degree of HLA matching was not specified in a number of studies, limiting the authors' ability to evaluate HLA mismatch and the impact on safety. It is likely that in some instances participants received UCB with $<4 / 6$ matched HLA; however, this cannot be confirmed. Most trials were small, and follow-up durations were generally short. Thus, it will be important to continue to collect complete and longer-term safety data as larger trials get underway to ensure that any rare AEs are captured. Finally, the conclusions of this study are restricted by the heterogeneity of treatment approaches and diseases treated.

\section{Conclusions}

Allogeneic UCB infusions for the treatment of neurological conditions are considered safe and are not associated with significant infusional toxicities or reports of GVHD or teratoma development. The available data do not identify safety concerns with infusion of pooled UCB units from multiple donors or repeat dosing with/without HLA matching and immunosuppression protocols. The results of this review support the safety of allogeneic UCB and may enable more flexibility (i.e., less stringent HLA matching and use of immunosuppression) in how allogeneic UCB can be applied in neurological and other non-myeloablative settings. The next necessary step is to continue confirming efficacy in these conditions while collecting longerterm safety data.

\section{Declaration of Competing Interest}

The authors have no commercial, proprietary or financial interest in the products or companies described in this article.

\section{Funding}

No funding was received.

\section{Author Contributions}

Conception and design of the study: MCBP and MFE. Acquisition of data: MCBP, GC and MFE. Analysis and interpretation of data: MCBP, DAW, NE, KC, IN and MFE. Drafting or revising the manuscript: MCBP, DAW, NE, KC, GC, IN and MFE. All authors have approved the final article.

\section{Supplementary materials}

Supplementary material associated with this article can be found in the online version at doi:10.1016/j.jcyt.2021.07.001.

\section{References}

[1] Song CG, Zhang YZ, Wu HN, Cao XL, Guo CJ, Li YQ et al. Stem cells: a promising candidate to treat neurological disorders. Neural Regen Res 2018;13(7):1294304. 
[2] Sun JM, Kurtzberg J. Stem cell therapies in cerebral palsy and autism spectrum disorder. Developmental Medicine \& Child Neurology 2021;63:503-10.

[3] Castillo-Melendez M, Yawno T, Jenkin G, Miller SL. Stem cell therapy to protect and repair the developing brain: an overview of mechanisms of action of cord blood and amnion epithelial derived cells. Frontiers in Neuroscience 2013;7:194.

[4] Bennet L, Tan S, Van den Heuij L, Derrick M, Groenendaal F, van Bel F, et al. Cell therapy for neonatal hypoxia-ischemia and cerebral palsy. Annals of neurology 2012;71(5):589-600.

[5] Ilic D, Miere C, Lazic E. Umbilical cord blood stem cells: clinical trials in nonhematological disorders. Br Med Bull 2012;102:43-57.

[6] Sun JM, Song AW, Case LE, Mikati MA, Gustafson KE, Simmons R, et al. Effect of autologous cord blood infusion on motor function and brain connectivity in young children with cerebral palsy: a randomized, placebo-controlled trial. Stem Cells Transl Med 2017;6(12):2071-8.

[7] McDonald CA, Castillo-Melendez M, Penny TR, Jenkin G, Miller SL. Umbilical Cord Blood Cells for Perinatal Brain Injury: The Right Cells at the Right Time? Umbilical Cord Blood Banking for Clinical Application and Regenerative Medicine: In-Tech 2017; In-Tech:101-31. https://doi.org/10.5772/66647.

[8] Sanberg PR, Ehrhart J. A Hallmark Clinical Study of Cord Blood Therapy in Adults with Ischemic Stroke. Cell Transplant 2019;28(9-10):1329-32.

[9] Sanberg PR, Eve DJ, Cruz LE, Borlongan CV. Neurological disorders and the potential role for stem cells as a therapy. Br Med Bull 2012;101:163-81.

[10] Paton MCB, Finch-Edmondson M, Fahey MC, London J, Badawi N, Novak I. Fifteen years of human research using stem cells for cerebral palsy: a review of the research landscape. J Paediatr Child Health 2021;57(2):295-6.

[11] Blazar BR, Hill GR, Murphy WJ. Dissecting the biology of allogeneic HSCT to enhance the GvT effect whilst minimizing GvHD. Nat Rev Clin Oncol 2020;17 (8):475-92.

[12] Stavropoulos-Giokas C, Dinou A, Papassavas A. The Role of HLA in Cord Blood Transplantation. Bone Marrow Res 2012;2012:485160.

[13] Pan B, Lazarus HM, Gale RP. Microtransplantation for Acute Myeloid Leukemia: A Systematic Review. JAMA Oncol 2020;6(10):1614-20.

[14] Damien P, Allan DS. Regerative therapy and immune modulation using umbilical cord blood-derived cells. Biology of Blood and Marrow Transplantation 2015;21 (9):1545-54.

[15] Mayani H, Wagner JE, Broxmeyer HE. Cord blood research, banking, and transplantation: achievements, challenges, and perspectives. Bone Marrow Transplant 2020;55(1):48-61.

[16] Torre P, Flores AI. Current Status and Future Prospects of Perinatal Stem Cells Genes 2020;12(1):6.

[17] Murad MH, Sultan S, Haffar S, Bazerbachi F. Methodological quality and synthesis of case series and case reports. BMJ Evidence-Based Medicine 2018;23 (2):60-3.

[18] Min K, Song J, Kang JY, Ko J, Ryu JS, Kang MS, et al. Umbilical Cord Blood Therapy Potentiated with Erythropoietin for Children with Cerebral Palsy: A Double-blind, Randomized, Placebo-Controlled Trial. Stem cells 2013;31(3):581-91. a.

[19] Min K, Songa J, Lee JH, Kang MS, Jang SJ, Kim SH, et al. Allogenic umbilical cord blood therapy combined with erythropoietin for patients with severe traumatic brain injury: three case reports. Restorative Neurology and Neuroscience 2013;31:397-410. b.

[20] Min K, Suh MR, Cho KH, Park W, Kang MS, Jang S], et al. Potentiation of cord blood cell therapy with erythropoietin for children with CP: a $2 \times 2$ factorial randomized placebo-controlled trial. Stem Cell Res Ther 2020;11(1):509.

[21] Laskowitz DT, Bennett ER, Durham RJ, Volpi JJ, Wiese JR, Frankel M, et al. Allogeneic Umbilical Cord Blood Infusion for Adults with Ischemic Stroke: Clinical Outcomes from a Phase I Safety Study. Stem Cells Transl Med 2018;7(7):521-9.

[22] Dawson G, Sun JM, Baker J, Carpenter K, Compton S, Deaver M, et al. A Phase I Randomized Clinical Trial of the Safety and Efficacy of Intravenous Umbilical Cord Blood Infusion for Treatment of Children with Autism Spectrum Disorder. J Pediatr 2020;222:164-73 e5.
[23] Sun J, Mikati M, Troy J, Mclaughlin C, Jasien J, Case L, et al. Sibling umbilical cord blood infusion is safe in children with cerebral palsy. Developmental Medicine \& Child Neurology 2017;59(S3):115.

[24] Romanov YA, Tarakanov OP, Radaev SM, Dugina TN, Ryaskina SS, Darevskaya AN, et al. Human allogeneic ABO/Rh-identical umbilical cord blood cells in the treatment of juvenile patients with cerebral palsy. Cytotherapy 2015;17(7):969-78.

[25] Feng M, Lu A, Gao H, Qian C, Zhang J, Lin T, et al. Safety of Allogeneic Umbilical Cord Blood Stem Cells Therapy in Patients with Severe Cerebral Palsy: A Retrospective Study. Stem cells international 2015;2015:1-7. 325652.

[26] Kang M, Min K, Jang J, Kim SC, Kang MS, Jang SJ, et al. Involvement of Immune Responses in the Efficacy of Cord Blood Cell Therapy for Cerebral Palsy. Stem cells and development 2015;24(19):2259-68.

[27] Vyas R, Dudhat D, Sudhalkar N, Garg V, Thadani J, Marathe A, et al. Clinical safety in using unmatched allogeneic umbilical cord blood mononuclear cells transplantation in non-haematopoietic degenerative conditions. Journal of Stem Cells 2014;9(4):219-24.

[28] Sun JM, Case LE, Mikati MA, Jasien J, McLaughlin C, Waters-Pick B, et al. Sibling umbilical cord blood infusion is safe in young children with cerebral palsy. STEM CELLS Translational Medicine 2021:1-8. https://doi.org/10.1002/sctm.200470. (Online only).

[29] Lalu MM, McIntyre L, Pugliese C, Fergusson D, Winston BW, Marshall JC, et al. Safety of cell therapy with mesenchymal stromal cells (SafeCell): a systematic review and meta-analysis of clinical trials. PLoS One 2012;7(10):e47559.

[30] Bloor AJC, Patel A, Griffin JE, Gilleece MH, Radia R, Yeung DT, et al. Production, safety and efficacy of iPSC-derived mesenchymal stromal cells in acute steroidresistant graft versus host disease: a phase I, multicenter, open-label, dose-escalation study. Nat Med 2020;26:1720-5.

[31] Riordan NH, Hincapie ML, Morales I, Fernandez G, Allen N, Leu C, et al. Allogeneic Human Umbilical Cord Mesenchymal Stem Cells for the Treatment of Autism Spectrum Disorder in Children: Safety Profile and Effect on Cytokine Levels. Stem Cells Transl Med. 2019;8(10):1008-16.

[32] Matthay MA, Calfee CS, Zhuo H, Thompson BT, Wilson JG, Levitt JE, et al. Treatment with allogeneic mesenchymal stromal cells for moderate to severe acute respiratory distress syndrome (START study): a randomised phase 2a safety trial. The Lancet Respiratory Medicine 2019;7(2):154-62.

[33] Fadeyi EA, Saha AK, Naal T, Martin H, Fenu E, Simmons JH, et al. A comparison between leukocyte reduced low titer whole blood vs non-leukocyte reduced low titer whole blood for massive transfusion activation. Transfusion 2020;60 (12):2834-40.

[34] Utter GH, Nathens AB, Lee TH, Reed WF, Owings JT, Nester TA, et al. Leukoreduction of blood transfusions does not diminish transfusion-associated microchimerism in trauma patients. Transfusion 2006;46(11):1863-9.

[35] Jackman RP, Utter GH, Lee TH, Montalvo L, Wen L, Chafets D, et al. Lack of persistent microchimerism in contemporary transfused trauma patients. Transfusion 2019:59(11):3329-36.

[36] Schiava N, Mathevet JL, Boudjelit T, Arsicot M, Feugier P, Lermusiaux P, et al. Cryopreserved Arterial Allografts and ABO and Rhesus Compatibility. Ann Vasc Surg 2016;33:173-80

[37] Riordan NH, Chan K, Marleau AM, Ichim TE. Cord blood in regenerative medicine: do we need immune suppression? J Transl Med 2007;5:8.

[38] Rees L, Kim JJ. HLA sensitisation: can it be prevented? Pediatr Nephrol 2015;30 (4):577-87.

[39] Bae SH, Kong TH, Lee HS, Kim KS, Hong KS, Chopp M, et al. Long-lasting paracrine effects of human cord blood cells on damaged neocortex in an animal model of cerebral palsy. Cell Transplant 2012:21(11):2497-515.

[40] Maillacheruvu PF, Engel LM, Crum IT, Agrawal DK, Peeples ES. From cord to caudate: Characterizing umbilical cord blood stem cells and their paracrine interactions with the injured brain. Pediatr Res 2017;83(1-2):205-13.

[41] Crompton K, Novak I, Fahey M, Badawi N, Wallace E, Lee K, et al. Single group multisite safety trial of sibling cord blood cell infusion to children with cerebral palsy: study protocol and rationale. BMJ Open 2020;10(3):e034974 